investigation by the owner, and has proved rich in finds. Of these, one of the most interesting, according to a preliminary account which appeared in The Times of January 24, is a structure, which proved to be the abutment of a bridge carrying a track over a ditch. On the east side of the track were two cremation burials and on the west side forty-two cremation burials and two inhumations, one of a child and one of an adult. No sort of order or alignment seems to have been observed. None of the pottery is certainly later than A.D. 160, but it is interesting as showing the development in design from Belgic to Roman. Of the forty-four cremation burials twenty-one consisted of the urn only; but the remaining twenty-three included smaller vessels, beakers, jugs, dishes of Samian ware, and a small glass tear bottle. A report by Dr. Davey will be presented to the Society shortly.

\section{Empire Exhibition at Johannesburg}

THE rapid development of South Africa was outlined by Lord Riverdale of Sheffield, speaking on January 23, under the auspices of the British Empire League, at the British Empire Club. His main subject was the Empire Exhibition which is to be opened in Johannesburg on September 15. Last year marked the twenty-fifth anniversary of the Union of South Africa; between 1910 and 1935 the European population increased by more than fifty per cent and the native population by more than forty per cent. These important years have seen a tremendous increase in agricultural products and mineral development. Conspicuous progress has been made in the fruit industry, the value of exports of fresh fruit having risen from an average of $£ 15,000$ a year in pre-War years to $£ 2,270,000$ in 1934 . In recent years rapid industrial development has also taken place. As an export market for United Kingdom goods, South Africa ranks second only to British India, and in 1934 took goods to the value of some

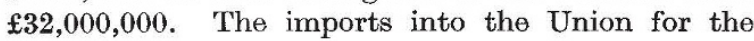
first six months of 1935 showed an increase of $£ 5,600,000$, and of this total the United Kingdom supplied forty-nine per cent. This will be the first Empire Exhibition which has been held outside Great Britain and is receiving the full support of the Union of South Africa Government and the Government of Great Britain. After enumerating many of the features of the forthcoming exhibition, Lord Riverdale said that, from a business point of view, he could thoroughly recommend it as being an opportunity of showing what British manufacturers can do for the South African market with a view to the expansion of our trade. In metals and manufactures, including machinery and vehicles, South Africa imported more than $£ 24,000,000$ in 1934, and Great Britain supplied only $£ 12,000,000$ in this item alone. If the market was studied and our goods shown in the right way, there lies a large field for further expansion. The same might be said for the item of fibres, yarns, textiles and apparel. In 1934 the Union's total imports for these were $15 \frac{1}{2}$ millions, of which the United Kingdom's share was less than $£ 10,000,000$.

\section{The National Institute of Sciences of India}

WE welcomed recently (NATuRE, 135, 59, 410 (1935) ) the formation in India of the National Institute of Sciences, a major function of which will be the co-ordination of the activities of the three co-operating academies in Calcutta, Allahabad and Bangalore. We have now received the first two volumes of the Proceedings of the now Institute. The first volume contains a full account of the inaugural meeting together with a list of the foundation fellows. We have referred already to the scholarly address by the president, Sir Lewis Leigh Fermor, and a perusal of the list of foundation fellows shows that the Institute has received the enthusiastic support of all men of science working in India. In the past, India has suffered in that it has had no body of organised scientific opinion capable of representing it at international conferences. It is not the least notable of the functions performed by the Indian Science Congress that it has been responsible for the foundation of the Indian Institute of Sciences, which will supply this want.

THE second volume of the Proceedings prints a number of scientific communications read before the Institute. They cover a wide field of research since they comprise papers on botanical, anthropological, physical and chemical subjects. We had not anticipated from the president's inaugural address that the Institute would, in other than exceptional circumstances, act as a publishing body; but that it was to be concerned rather with the publication of summaries of papers read before the co-operating academies. We regard it as somewhat unfortunate that there should be an increase in the large number of journals already published in India. Of greater interest than the specialist papers is the account of the symposium on "Problems of the Ionosphere". The holding of these general discussions on varied subjects of scientific importance will, we think, prove to be one of the most notable activities of the National Institute, and if they maintain the high standard of the first symposium, original work in India will receive a marked stimulus.

\section{Recent Acquisitions at the Natural History Museum}

Amovg recent additions to the zoological collections are specimens of Ungulate mammals from the Sudan presented by Major P. H. G. Powell-Cotton and Miss Diana Powell-Cotton. A fine specimen of adult beaver from Norway has been purchased, and an interesting series of Crustacea from the Bering Sea and the Sea of Okhotsk, regions previously very poorly represented in the Museum collection, have been received by exchange. A specimen of a rare mollusc, Halicardia flexuosa, from the Atlantic Ocean off Cape Point, South Africa, has been presented by the director of the South African Museum, Cape Town. The Department of Geology has recently acquired, through the generosity of the Committee of the Torquay Natural History Society, more than 160 Devonian invertebrates from Devon, all of which are type or figured specimens ; and has received from 